\title{
An Empirical Study Analyzing the ATM Service Quality and Customer Satisfaction Relationship in Rwanda
}

\author{
Nshimiyimana Alexis ${ }^{1, ~ *}$, Wenpei Chen ${ }^{1,2}$ \\ ${ }^{1}$ Department of Economics and Management, Faculty of Management Science and Engineering, Chongqing University of Posts and \\ Telecommunications, Chongqing, China \\ ${ }^{2}$ Department of Economics and Management, Chongqing University of Posts and Telecommunications, Chongqing, China
}

Email address:

alnbello@gmail.com (N. Alexis), chenwp@cqupt.edu.cn (Wenpei Chen)

${ }^{*}$ Corresponding author

To cite this article:

Nshimiyimana Alexis, Wenpei Chen. An Empirical Study Analyzing the ATM Service Quality and Customer Satisfaction Relationship in Rwanda. International Journal of Business and Economics Research. Vol. 8, No. 6, 2019, pp. 439-451. doi: 10.11648/j.ijber.20190806.24

Received: November 4, 2019; Accepted: November 22, 2019; Published: December 2, 2019

\begin{abstract}
ATM as one type of Electronic banking systems have become a strategic technology in the banking sector by delivering banking products/services and are expected to offer competitive advantages to banks investing in ATM technology over those that do not. In Rwanda, the cash-based system is now gradually being replaced by the card-based system and this requires banks to improve ATM service quality to satisfy customers. The aim of this paper was to conduct empirical evidence from ATM cardholders of five selected commercial banks in Rwanda to analyze the relationship between ATM service quality and customer satisfaction. To achieve this objective, a structured questionnaire was used to collect primary data of 250 ATM users in five commercial banks from Kigali, capital city of Rwanda (Bank of Kigali, Cogebanque, Equity Bank, Banque Populaire du Rwanda Limited and Ecobank). The questionnaire consists mainly of 32 constructs observed under seven ATM service quality dimensions (Reliability, Responsiveness, Assurance, Empathy, Tangibles, ease of use and Convenience) and a five-point rating scale was adopted as the scale for the statements formulated in the questionnaire. Findings showed that $70.8 \%$ of respondents were under or equal to 35 years old which presents a range of youths in Rwanda. From the results, $70 \%$ of respondents claimed that they have never been educated on utilization of ATMs. Using SPSS, customer satisfaction has shown a strong correlation with all seven ATM service quality. The multiple regression results identified ease of use as the most important dimension on customer satisfaction and it was followed by convenience, empathy and Tangibles. Therefore, it is suggested that banks could improve their customer satisfaction ratings by educating customers to use ATM and not forget other important improvements in automated teller machine banking services.
\end{abstract}

Keywords: Automated Teller Machines (ATMs), Service Quality, Customer Satisfaction

\section{Introduction}

\subsection{Background of the Study}

The common challenges for modern business industry are the competition between companies that offer same products or services. Therefore, it is essential to know which improvements should be effected to enhance the level of customer satisfaction with innovative products or services that allow a successful offering to meet and exceed customers' expectations.

Customer satisfaction is described as a measure on how product or services supplied by organization meet customers' expectation and this is one of the important keys to ensure business is successful because customers' satisfaction will determine the market growth of the organization in the future [1]. Satisfaction is measured through the level of product quality, quality of service provided, location where the product or service is purchased, and price of the product or service.

Banks adopted ATMs to help them to achieve competitive advantages in the new era of delivering a high quality of service in safer, quicker and more effective way that satisfies their customers with the products/services offered. Automated teller machine (ATM) was introduced by financial institutions as an innovative technology that helps the customers to 
perform financial transactions without the need for a bank teller (cashier) and helps bank to satisfy its customers thru a high quality of services

If customer satisfaction is achieved, the firm benefits through retention of satisfied customers who make repeat purchases and word-of-mouth recommendations resulting in increased sales and profitability of the business [2].

In Rwanda, the development of money followed the same path as elsewhere in the world; following Rwanda's vision 2020 and the Smart Rwanda Master Plan, Rwanda envisions becoming a cashless economy by 2020 [3]. According to this vision of the government of Rwanda, the cash-based system is now gradually being replaced by the cards-based system using electronic banking systems.

Electronic banking systems enable customers to access banking services through intelligent electronic devices such as computer (Internet Banking), Personal Data Assistant (PDAs), Mobile Phones (Mobile Banking \& Mobile money), Point of sales Terminals (POS), Automated Teller Machines (ATMs), Credit card and Debit cards [4].

ATMs have therefore become a strategic technology in the banking sector by delivering banking products or services and are expected to offer competitive advantages to banks investing in ATM technology over those that do not and the investment in ATM technologies remains strategic as banks continue to invest in newer and more efficient ATM technologies to bolster delivery of an efficient banking experience [5].

The marketing literature makes it clear that a number of studies have been done on issues related to ATM service quality and customers' satisfaction in different countries like UK, USA, Australia, China, Botswana, Pakistan, India, Ethiopia, Ghana, Nigeria, and Vietnam.

However, insufficient work has been done on this issue in Rwanda and during the time of research the researcher found a small number of papers related to the use of ATMs in Rwanda.

Researcher observed that most of banking institutions in Rwanda have introduced the use of ATM cards but the problem of long queues of customers who need services at the banking hall instead of using ATMs is still unresolved [6]. According to the annual report of the National Bank of Rwanda, there is a $6 \%$ decrement of ATMs [3].

The major objective of this study was to investigate the question of Rwandan customers' satisfaction with the ATM service quality using the seven dimensions of ATM service quality (reliability, responsiveness, assurance, empathy, tangibles, ease of use and convenience).

The following three objectives are considered in this research:

1) To examine the important dimensions of ATM service quality.

2) To analyze the local customers' satisfaction with the present quality of service provided by the ATMs of Bank of Kigali, Cogebank, Equity Bank, Banque Populaire du Rwanda SA and Eco Bank.

3) To offer valuable suggestions to local Rwandan bank managers to improve ATM service of banks for the benefit of their customers nation-wide.

\subsection{Significance of the Study}

Automated teller machines (ATMs) have been adopted by banks globally as innovative equipment and a competitive weapon for banks to offer quick, safe and high quality of service to the customers. However, they are used differently from country to country, region to region, and from one bank to another to maximize profits and meet customers' satisfaction.

In the context of Rwanda, ATMs have been chosen by commercial banks for solving the problems of long queues that always appear in the banking halls. This study intends to collate empirical evidence from customers of commercial banks in Rwanda to analyze the relationship between ATM service quality and customer satisfaction.

The study and its proposed research with subsequent final recommendation is bound to be beneficial to the national Rwandan banking industry in order to enhance the quality of services by adopting a range of revised strategies to offer diverse improved services as expected by customers.

Additionally, it is expected to assist bank managers to (a) gain a more meaningful and informed insight into and an overview to what extent local Rwandan customers are satisfied with the ATM service quality and (b) advise them on improvements needed to increase levels of customer satisfaction.

This study will also hopefully play a crucial role for the future research focusing on the ATM service quality especial in the context of Rwanda.

The overall structure of the study takes the form of 6 sections, including this introductory section. Section two begins by laying out the theoretical dimensions of the research, and looks at how other related researches have been conducted (review of literature). The third section is concerned with the conceptual framework and hypotheses while the fourth section deals with the methodology of the study. Section five is concerned with data analysis while Section six discuss the results of data undertaken during this research. Finally, the conclusion gives a brief summary and critique of the findings; limitations and areas for future research are also identified in section seven.

\section{Literature Review}

This part examines relevant literatures from works that have already been done on ATM, service quality, customers' satisfaction and relationship between service quality and satisfaction of customers.

\subsection{Automated Teller Machine (ATM)}

The acronym of ATM which stands for Automated Teller Machine has been given numerous definitions by both scholars and practitioners seeing it as one of the most innovative banking devices. 
When banking industry introduced ATM machines, the banks perceived ATM to be able to reduce the unnecessary traffic in the banking hall, offer customers quick access to their accounts and make life convenient to a certain level [1].

ATM is a computerized telecommunication device that provides the customer of a financial institution with access to financial transactions in a public space without the need for a human cashier, clerk or bank teller [6].

Additionally, ATM has been defined as an electronic device which allows customers to deposit, withdraw, transfer money, pay bills and perform other financial transactions without the aid of a branch representative or a teller [7]. In other words, an automated teller machine (ATM) can be defined as an electronic telecommunications device that enables customers of financial institutions to perform financial transactions such as cash withdrawals, deposits, transfer money, checking balance or other information of customers' account at any time and without the need for interacting with bank staff.

In short, ATM is an innovative electronic device that allows banks customers to access the basic financial services without intervention of bank staff or tellers.

Nevertheless, not all ATMs perform or deliver financial services because some machines can only accept or withdraw money and check the balance, others can do more, i.e. withdraw, deposit, account balance, transfer money not to mention other services.

In Rwanda, ATM is one of self-service technologies which have shown an increasing capacity to provide services to customers outside the traditional banking halls. The annual report of National Bank of Rwanda shows that as for ATMs, there has been an increase of $5 \%$ in terms of volume and $10 \%$ in value of transactions [3].

\subsection{Service Quality (SQ)}

Nowadays it is crucial to ensure that a company is providing or offering a products or services with high quality that meet the customer needs as it can be an enduring offering and predict the future of that institution and the growth of it in the market place. Service quality is considered one of the critical success factors that influence the competitiveness of an organization [8].

According to the ATM performance, SQ is best defined by the consumer of the product or service. It is generally understood, however, that quality implies the totality of features and characteristics of a product or service that bears its ability to satisfy implied or stated needs of consumers [2].

Financial institutions are currently being pushed by both customers who are looking for a higher service quality and technology that is changing day by day, and this has become a reason for banks to adopt innovative products that will help them to serve customers in an easy, fast, innovative and satisfactory way compared to traditional systems.

ATM service quality is defined by as the customer's overall evaluation of the excellence of the provision of services through electronic networks such as Automated Teller Machine (ATM) [9]. Another study argued that ATM service quality is the customers' overall evaluation and judgment of excellence of services provided through ATM channels [7].

\subsection{Customers Satisfaction}

Customer satisfaction is described as a measure on how product or services supplied by organization meet customers' expectation and Satisfaction is measured through the level of product quality, quality of service provided, location where the product or service is purchased, and price of the product or service [1].

Customer satisfaction can be experienced in a variety of situations and connected to both goods and services and service quality is a highly personal assessment that is greatly affected by customer expectations [9].

Companies should put in place what should meet with their customers' needs to make it competitive in the market-place of delivering an expected service quality and maintain customer's loyalty.

Customer satisfaction measurement allows an organization to understand the key drivers that create satisfaction or dissatisfaction and what is really driving their satisfaction during a service experience [8].

The study conducted by Charles opined that customer satisfaction with ATM banking therefore is a response to the user experience of ATM banking which occurs at a particular time and is based on customers' accumulated experience of ATM banking services from their respective banks whereas the customer satisfaction with banks can be regarded as a culmination of banking experience enjoyed over time whether it meets expectations or not [5].

\subsection{Relationship Between Service Quality and Satisfaction of Customers}

Service quality and customer satisfaction are very important concepts which must be understood by companies that want to grow while keeping their competitive edge. In the previous study, a researcher noted that the higher level of perceived service quality results in increased customer satisfaction. When a perceived service quality is less than an expected service quality then a customer will be dissatisfied [10].

However, another study argued that customer satisfaction can be obtainable with low quality, whenever one's expectations in a given situation are low and a performance is adequate to the task. Emergency situations fit this scenario well. Similarly, dissatisfaction with high quality can ensue when some element of the service delivery is not up to personal expectations [11] cited by [10].

It is important that banks achieve service quality and customer satisfaction to remain competitive through ATMs [2]. Whenever banks provide a promised ATM services, customer will no longer need to stay for a long time in bank queues to be served by a bank teller or staff but they can access all basic financial services using ATMs.

To examine the satisfaction of customers, both researchers and practitioners have conducted researches on service quality 
and customer satisfaction in the entire world and the most used models include, inter alia, SERVQUAL, SURVPRF, ATMqual, BANKSERV. The results from different studies have proved that service quality is the important antecedent of customer satisfaction [2, 4, 5, 9, 12-14].

The research titled "Impact of service quality on customer satisfaction of automated teller machine service: case study of a private commercial joint stock bank in Vietnam", by applying SERVPERF framework to analyze the data collected from a questionnaire survey, they found that ASSURANCE and TANGIBLES factors have a significant impact on the customer satisfaction [9].

With the aim to investigate the influence of ATM service quality on customer satisfaction in the banking sector of Nigeria, survey research and questionnaires administered were adopted on four banks and the study concludes that ATM service quality determines customer satisfaction [4].

In Rwanda, a study conducted on the Automated Teller Machines and Profitability of Commercial Banks in Rwanda [6]. The Research was conducted under a period from 2010 to 2016 with the aim to assess the use of ATM and its contribution to the profitability in bank of Kigali (BK). Using both quantitative and qualitative methods of data collection in the total population of 334,121 ATM users, a sample of 200 respondents were used and the findings showed that in BK still faces an obstacle of financial education (e.g., information or training) of the customer about how to use ATM cards in general. A hypothesis confirmed that there is a significant relationship between ATM and profitability of BK and lower cost, differentiation and accessibility are factors that determine levels of satisfaction among ATM users at BK and on the competitive market.

Another early study conducted in Ghana to study ATM service and Customer Satisfaction in the Upper East Region of Ghana suggested that Customer Satisfaction could be improved by convenience, security and privacy and reliability of the ATM services after analyzing primary data collected from 200 respondents using convenience and simple random sampling methods [15].

The results from a paper studied the effect of ATM service quality on customer satisfaction in Ethiopian commercial Banks indicated that with the exception of assurance, factors such as tangibility, reliability, responsiveness and empathy have positive and significant effect on customer satisfaction and the customers were mostly satisfied with the responsiveness dimensions of ATM service quality [16].

The performance-only (SURVPERF) measurement consists of five dimensions: tangibility, reliability, assurance, responsiveness, and empathy of service quality proposed by [11]. It has been used by more researchers in the world to measure service quality.

However, another researcher argued that the superiority of SERVPERF has primarily been validated in the Western service context, and due to cultural differences, it is likely that the cultural orientation of consumers will influence its applicability [17].

Therefore, in order to examine how customers are satisfied with the current ATM service quality of their banks in the context of Rwanda this study adopted seven dimensions including five dimensions of service quality described by [11]. And two extra components including Convenience and Ease of use adopted from ATMqual model used by [7].

These extra items were chosen from other items of ATMqual after discussing their importance in the context of ATM banking in Rwanda; ease of use refers to how easily system is to be accessed by users with tolerated barrier (interface, language and displays) and convenience refers to how conveniently an ATM is located. The seven dimensions adopted by the researcher to examine the customers' satisfaction with ATM service quality are therefore: reliability, responsiveness, assurance, empathy, tangibles, ease of use and convenience.

\section{Conceptual Framework and Hypotheses}

This section presents all variables, a conceptual framework and hypotheses that have been proposed to be used and test the significance of this study.

\subsection{Variables}

As mentioned in the literature review, seven independents variables and one dependent variable were adopted from the previous studies to assess the importance of ATM service quality on customer satisfaction in commercial banks of Rwanda. The following table indicates both independent (ATM service quality dimensions) and dependent (Customer satisfaction) variables and it clearly defines their sources.

Table 1. Variables.

\begin{tabular}{lll}
\hline Type of variable & Variable & Source \\
\hline & Reliability & \\
& Responsiveness & \\
& Assurance & {$[9]$} \\
Independents & Empathy & \\
& Tangibles & {$[7]$} \\
& Ease of use & \\
& Convenience & Customer satisfaction \\
Dependent & {$[13]$} \\
\hline
\end{tabular}

\subsection{Definition of Variables}

\subsubsection{Independent Variables}

This study adopted service quality of ATMs as independent variable to examine its effect on customer satisfaction in commercial banks of Rwanda. As service quality is most likely to affect customer satisfaction which in turn leads to repeat use, positive words of mouth, referrals and the like; most firms try to measure their service quality in order to ensure the satisfaction of their customers [13]. Additionally, a number of researchers have reported service quality as an antecedent of customer satisfaction $[4,5,8,9,13]$.

In this study we examined service quality by considering seven independent variables including:

1) Reliability, defined as the ability of an organization to 
accurately achieve its services in the proper time and according to the promises it has made to its clients $[9,12$, 13].

2) Responsiveness, the tendency and willingness of service providers to help clients and satisfy their needs, immediately reply to their inquiries, and solve their problems as quickly as possible [9, 12].

3) Assurance, assurance is the feelings of trust and confidence in dealing with the organization. This reflects the workers' knowledge and experience and their ability to build self-confidence as well as confidence in the customers themselves [9, 12].

4) Empathy refers to understanding the customers' personal needs, taking care of them individually and showing them various levels of sympathy and affection, looking at them as close friends and distinguished clients [12]. In addition, empathy defined as the willingness or readiness of employees to help customers and provide services [9].

5) Tangibles includes physical aspects connected with service such as instruments and equipment, persons, physical facilities like buildings and pleasant decoration and other observable service facilities $[9,12]$.

6) Vis-à-vis Ease of use researcher notes that ease of use is the degree to which the prospective user expects the target system to be free of effort [7].

7) As for Convenience, location convenience refers to the sites and locations at which the ATMs are located [7].

\subsubsection{Dependent Variable}

As pointed out customer satisfaction remains a crucial performance indicator in the business and frequently forms part of a balanced scorecard [13]. The concept of customer satisfaction has become an important concept in both operation and marketing firms as it can determine the future of a company.

Customers always try to compare what they receive to their expectation or needs, thus it important to know what a firm has to deliver to its customers. Financial institutions found that customers need a quick, safe and error free service and they adopted ATM as solution to this.

In the banking sector, it is important that banks achieve service quality and customer satisfaction to remain competitive through ATMs [2].

\subsection{Conceptual Framework}

After defining all variables, a conceptual framework was created to guide this study and it is created based on defined independent and dependent variables. It is also used to present proposed hypotheses.

The following conceptual framework consists of four parts in which the first part presents seven service quality dimensions (Independents variables), the second part is a dependent variable (customer satisfaction), and the third part presents the seven arrows that show the relationship between independent variables and dependent variable while the last part shows seven proposed hypotheses ( $\mathrm{H} 1, \mathrm{H} 2, \mathrm{H} 3, \mathrm{H} 4, \mathrm{H} 5, \mathrm{H} 6$ and H7).

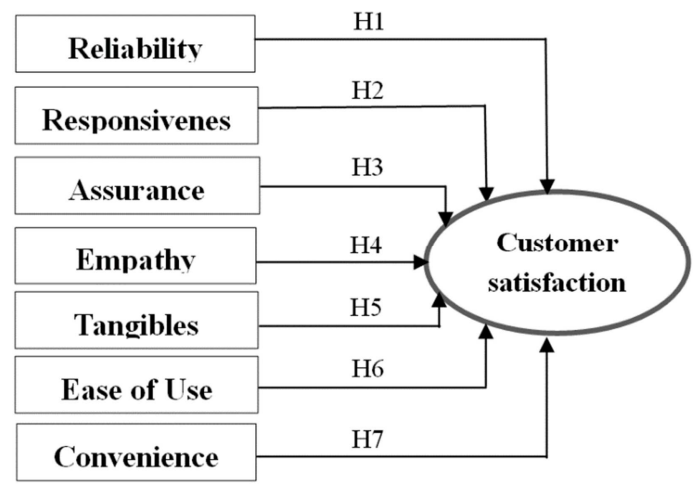

Figure 1. Conceptual framework.

\subsection{Hypotheses}

A hypothesis is an idea that a researcher then tests through study and experimentation. A hypothesis is often speculative but is not a well-recognized theory. In research, a hypothesis needs to go through a lot of testing in advance before it gets labelled a theory. Based on the presented framework and the objectives of the study, seven hypotheses have been proposed to analyze the relationship between ATM service quality and customer satisfaction in commercial banks of Rwanda. A researcher reminds readers that each hypothesis represents a specific relationship that must be specified [18]. The following seven hypotheses were proposed in this study:

Reliability: previous studies have reported reliability of ATM service to be the most important determinant of overall ATM service quality and strongest predictor of customer satisfaction in electronic channels. A study reports that within the ATM environment, technical reliability may be equated to the design and installation of the ATM while functional reliability may also denote the performance of the ATM (e.g. the ability of the ATM to provide error-free services) [7]. The reliability dimension is critical because it embeds the dynamic capability to perform the promised service dependably and accurately [19]. Reliability refers to the ability to deliver expected standards at all times, how the organization handles customer services problems, performing right services for the first time, providing services within promised time and maintaining an error-free record [1].

Another study argues that Reliability of banking services therefore means that there must be accuracy in billing; keeping accurate records as well as performing the service at the designated time and by using the model to study retail bank service quality, he found reliability to be the most significant dimension of service quality that predicted customer satisfaction [20].

Studies of ATM service quality have showed the importance of reliability among the dimensions of retail service quality that positively and significantly predicted customer satisfaction [2, 7, 19, 21]. Therefore, the study proposed hypothesis one (H1) and is stated as:

H1: Reliability has a significant relationship with customer's satisfaction.

Responsiveness: Responsiveness deals with the willingness 
to help customers, ability to provide prompt services and also the management of failures when they occur [4].

With ATMs, responsiveness quality deals with the banks' ability to handle customer complaints arising as a result of transactional failures and the author adds that acceptable recovery practices may vary from a simple apology to compensating customers against losses incurred such as monies illegally withdrawn from their accounts [7].

Many studies on ATM service quality used SERVQUAL and SERVPERF dimension to measure service quality effect on customer satisfaction and their results have identified responsiveness as one of the predictive dimensions of customer satisfaction $[4,7,8]$.

On the basis of their findings, a second hypothesis was formulated:

H2: Responsiveness has a significant relationship with customer's satisfaction.

Assurance corresponds to the knowledge and courtesy of employees and their ability to inspire trust and confidence [22]. The researchers found assurance to be most important service quality dimension on customer satisfaction $[9,12]$.

The hypothesis H3 proposed is based on the above result and reads as follows:

H3: Assurance has a significant relationship with customer's satisfaction.

Empathy: it has been noted that as far as 'Empathy' is concerned, it includes elements like providing service in terms of place, time, communication, and to what extent the service provider understands the beneficiary [12]. Empathy is another important dimension used proposed in different models including SERVQUAL, SERVPERF and GIQUAL to measure service quality.

Previous findings showed that the construct Empathy exerted the highest predictive strength and has a positive and significant effect on overall satisfaction $[4,16]$.

Therefore, the next hypothesis H4 is stated as:

H4: Empathy has a significant relationship with customer's satisfaction.

Tangibles: the result of the study found that tangibles dimension has significant influence on customer satisfaction [9]. And this result has been supported by other studies on service quality including $[4,8,16,20]$. Thus, itis hypothesized that:

H5: Tangibles have a significant relationship with customer's satisfaction.

Ease of use: ATMs like other self-service technologies have to be user friendly for customers who use them as these customers can be challenged with their functionality, interface or languages displayed when they want to access it. That means that banks and ATM service providers should be certain that system used is well designed and tested to the needs of customers. Technology could sometimes be intimidating to some customers and, therefore, one expects that an ATM should be able to simplify this to the barest minimum so as to motivate customers to use the facility [7].

The following hypothesis has been proposed based on the above argument and researcher's experience on the use of ATM:
H6: Ease of use has a significant relationship with customer's satisfaction.

Convenience: Locational convenience of ATMs refers to the site at which the ATMs are located. As the ATM offers an alternative way of conducting banking transactions outside the banking halls, locational convenience of the ATM sites is also an important quality determinant [7]. In addition, most ATMs are located in bank branches, or off sites such as in shopping malls and at college campuses.

When ATMs are located in public places and not far from the customers, they allow for making financial transactions without taking a long distance to look for ATMs terminals. Customers can also access other banks' ATMs when there is inter-bank networking which allows a customer to make transaction at affordable charges. Frequently the bank's ATM card is compatible with other banks' ATM platforms and this makes it possible for customers to withdraw money from other ATMs at a small fee [7].

Therefore, the last hypothesis is proposed and stated as:

H7: Convenience has a significant relationship with customer's satisfaction.

\section{Research Methodology}

A research methodology is the way of systematically solving the research problem [23]. The research methodology enlightens the methods to be followed in research activities starting from investigation to presentation.

The objective of this study is to provide empirical evidence for academics and practitioners by investigating the impact of the ATM service quality on the satisfaction of customers of commercial banks in Rwanda using seven service quality dimensions.

\subsection{Development of the Scale}

The scale of the study was developed through the review of the main measurement scales used in previous studies related to ATM service quality and customers' satisfaction.

The questionnaire survey consists mainly of 32 items observed under the SERVPERF model and the ATMqual model that used to measure service quality of ATMs, in which 29 items are divided into seven components of service quality and ATM quality: Reliability (5 items), Responsiveness (4 items), Assurance (5 items), Empathy (3 items), Tangible ( 3 items), Ease of use ( 5 items) and Convenience (4 items).

The remaining three variables (3 items) are used to measure customer satisfaction.

In order to measure those items, a five-point rating scale was adopted as the scale for the statements formulated in the questionnaire and it is corresponding to $1=$ Strongly Disagree, 2=Disagree, $3=$ Neutral, 4=Agree and 5=Strongly Agree.

\subsection{Data Collection}

In this study both primary and secondary data have been used. Primary data were obtained from the questionnaire 
administration while secondary data have been obtained from a literature-based research involving an examination of relevant papers from journals, official publications, textbooks, banks records and other sources on the internet.

To collect primary data, a number of five commercial banks in Rwanda were randomly selected by the researcher and the paper survey method was used. Copies of a questionnaire were sent to different ATM terminals of selected banks in Kigali city and trained assistants collected data from respondents who came to access ATM services.

The questionnaire used in this study was composed of two parts, the first part of questionnaire was designed to collect demographic data of the respondents that included address, age group, gender, education level, occupation, monthly income, ATM service, and how they often use ATM and training on utilization of ATM.

The second part of the questionnaire was the measurement scales that comprised 29 ATM service quality attributes and three attributes of customer satisfaction adopted from previous studies.

Since this study did not intend to measure quality perception in relation to any particular bank, participants in this study were randomly approached to fill up designed questionnaires. To avoid response-bias related to location, date and time, surveys were conducted at different locations, on different days as well as at uniformly distributed time intervals and were conducted in an identical manner in all five banks for the sake of consistency.

The criteria of five samples for an observed variable have been recommended by [9]. Thus, sample size for this study equals to $n=32 \times 5$, that means at least 160 respondents are accepted for this study.

To achieve this target, two hundred seventy questionnaires were distributed to customers (only ATM users) of five Commercial banks in Kigali. However, after verifying all questionnaires back, a total of 250 useable copies of the questionnaires were used for further tests and other 20 copies were not considered as they were not fully completed by respondents.

\subsection{Data Analysis and Interpretation}

To analyze data collected from respondents, a Statistical Package for the Social Sciences (SPSS statistics 23) was used. Cronbach's alpha was used to test reliability of variables, multiple regression tests the hypotheses that guide the study by investigating the effect of service quality dimensions (reliability, responsiveness, assurance, empathy, tangibles, ease of use and convenience) on customer satisfaction.

Descriptive statistics of mean and standard deviation, tables and graphs present the data collected from respondents.

\section{Data Analysis}

\subsection{Sampling Framework}

The questionnaire survey was developed for collecting data to analyze the customer's satisfaction with ATMs service quality in the context of Rwanda. Table 2 displayed the frequencies and percentages of respondents and the results show that respondents are not equally distributed per banks. Frequency results demonstrate that the bank with majority respondents is Bank of Kigali with $29.2 \%(n=73)$ respondents, it is followed by Banque Populaire du Rwanda Limited which has $20.8 \%(n=52)$ respondents, Equity Bank has 20\% $(n=50)$ respondents, Cogebanque16.8\% $(n=42)$ respondents and Ecobank has $13.2 \%(n=33)$ respondents.

Table 2. Sampling Framework.

\begin{tabular}{lll}
\hline Bank & Frequency & Percent (\%) \\
\hline Bank of Kigali & 73 & 29.2 \\
Cogebanque & 42 & 16.8 \\
Equity Bank & 50 & 20 \\
Banque Populaire du Rwanda Limited & 52 & 20.8 \\
Ecobank & 33 & 13.2 \\
Total & 250 & 100 \\
\hline
\end{tabular}

\subsection{Demographic Profile of Respondents}

Table 4 displayed the results of demographic information including address, age group, gender, education level, occupation, monthly income, ATM service, how often customers use ATM and information about being trained in the use of ATM.

\subsection{Reliability Analysis}

This method assists analysts in removing irrelevant variables [9]. The internal reliability of the seven independent variables and one dependent variable was analyzed through Cronbach's alpha coefficient and they were accepted as they satisfied the general agreed upon lower limit for Cronbach's alpha of .70 as postulated by [8].

The result displayed in Table 3 shows that all variables were maintained because they had Cronbach's alpha values between 0.718 and 0.905 .

Table 3. Reliability of constructs.

\begin{tabular}{llll}
\hline Constructs & Cronbach's Alpha & N of items & N \\
\hline Reliability & .905 & 5 & 250 \\
Responsiveness & .745 & 4 & 250 \\
Assurance & .893 & 5 & 250 \\
Empathy & .799 & 3 & 250 \\
Tangibles & .789 & 3 & 250 \\
Ease_Use & .877 & 5 & 250 \\
Convenience & .816 & 4 & 250 \\
Customer Satisfaction & .718 & 3 & 250 \\
All items reliability & .919 & 32 & 250 \\
\hline
\end{tabular}


Table 4. Demographic profile of respondents $(N=250)$

\begin{tabular}{|c|c|c|c|}
\hline Variables & Category & Frequency & Percent (\%) \\
\hline \multirow{5}{*}{ Address } & GASABO & 97 & 38.8 \\
\hline & KICUKIRO & 84 & 33.6 \\
\hline & NYARUGENGE & 69 & 27.6 \\
\hline & Total & 250 & 100 \\
\hline & Below 25 & 22 & 8.8 \\
\hline \multirow{5}{*}{ Age } & $26-35$ & 155 & 62 \\
\hline & $36-45$ & 45 & 18 \\
\hline & $46-55$ & 14 & 5.6 \\
\hline & Above 56 & 14 & 5.6 \\
\hline & Total & 250 & 100 \\
\hline \multirow{3}{*}{ Gender } & Male & 195 & 78 \\
\hline & Female & 55 & 22 \\
\hline & Total & 250 & 100 \\
\hline \multirow{6}{*}{ Education } & Up to Primary school & 8 & 3.2 \\
\hline & High school & 52 & 20.8 \\
\hline & Graduate & 144 & 57.6 \\
\hline & Post-graduate & 43 & 17.2 \\
\hline & Other & 3 & 1.2 \\
\hline & Total & 250 & 100 \\
\hline \multirow{7}{*}{ Occupation } & Employee & 135 & 54 \\
\hline & Businessman/woman & 69 & 27.6 \\
\hline & Student & 19 & 7.6 \\
\hline & Professional & 25 & 10 \\
\hline & Retired & 1 & 0.4 \\
\hline & Other & 1 & 0.4 \\
\hline & Total & 250 & 100 \\
\hline \multirow{8}{*}{ Monthly income (in Frw) } & $0-50,000$ & 34 & 13.6 \\
\hline & $50,001-100,000$ & 51 & 20.4 \\
\hline & $100,001-200,000$ & 47 & 18.8 \\
\hline & $200,001-300,000$ & 41 & 16.4 \\
\hline & $300,001-400,000$ & 20 & 8 \\
\hline & $400,001-500,000$ & 17 & 6.8 \\
\hline & 500,001 and above & 40 & 16 \\
\hline & Total & 250 & 100 \\
\hline \multirow{8}{*}{ ATM services } & Withdraw money, Deposit \& Check account Balance & 13 & 5.2 \\
\hline & Withdraw money \& Deposit & 3 & 1.2 \\
\hline & Withdraw money \& Check account Balance & 100 & 40 \\
\hline & Deposit \& Check account Balance & 4 & 1.6 \\
\hline & Only Withdraw money & 126 & 50.4 \\
\hline & Only Deposit & 1 & 0.4 \\
\hline & Only Check account Balance & 3 & 1.2 \\
\hline & Total & 250 & 100 \\
\hline \multirow{7}{*}{ How_often_use ATM } & Once a week & 57 & 22.8 \\
\hline & On alternate day & 81 & 32.4 \\
\hline & Three times a week & 18 & 7.2 \\
\hline & Four times a week & 13 & 5.2 \\
\hline & Once a month & 69 & 27.6 \\
\hline & Everyday & 12 & 4.8 \\
\hline & Total & 250 & 100 \\
\hline \multirow{3}{*}{ Educated_on_Use of ATM } & Yes & 75 & 30 \\
\hline & No & 175 & 70 \\
\hline & Total & 250 & 100 \\
\hline
\end{tabular}

\subsection{Exploratory Factor Analysis}

In EFA, the KMO index (Kaiser - Meyer - Olkin) is used to measure the adequacy of responses given with the sample to determine if response from the sample is adequate or not and $\mathrm{KMO}$ values of greater than 0.5 is acceptable.

$\mathrm{KMO}$ and Barlett's test in factor analysis from Table 5 shows that KMO values for all the eight constructs equal to .947 (greater than 0.5 ) and with the significance equals to ( $\mathrm{Sig}=.000 ; \mathrm{p}<0.001)$, hence suggesting that factor analysis is appropriate for the data.

Table 5. KMO and Bartlett's Test.

\begin{tabular}{lll}
\hline \multicolumn{2}{l}{ Kaiser-Meyer-Olkin Measure of Sampling Adequacy. } & $\mathbf{. 9 4 7}$ \\
\hline \multirow{3}{*}{ Bartlett's Test of Sphericity } & Approx. Chi-Square & 6050.263 \\
& df & 496 \\
& Sig. & .000 \\
\hline
\end{tabular}

With the rotated component matrix, thirty-two (32) variables were rotated using the Varimax rotation with Kaiser Normalization. The results displayed by Table 6 indicated that 
all 32 variables loaded onto eight factors loading coefficients greater than 0.5 and there was no cross-loading on any factor.

Table 6. Rotated Component Matrix ${ }^{a}$.

\begin{tabular}{|c|c|c|c|c|c|c|c|c|}
\hline \multicolumn{9}{|c|}{ Component } \\
\hline & 1 & 2 & 3 & 4 & 5 & 6 & 7 & 8 \\
\hline $\mathrm{R} 1$ & .819 & & & & & & & \\
\hline $\mathrm{R} 2$ & .798 & & & & & & & \\
\hline R3 & .794 & & & & & & & \\
\hline R4 & .777 & & & & & & & \\
\hline R5 & .668 & & & & & & & \\
\hline RS1 & & & & & & .864 & & \\
\hline $\mathrm{RS} 2$ & & & & & & .864 & & \\
\hline RS3 & & & & & & .851 & & \\
\hline RS4 & & & & & & .589 & & \\
\hline A1 & & & & & & & & .611 \\
\hline $\mathrm{A} 2$ & & & & & & & & .649 \\
\hline A3 & & & & & & & & .572 \\
\hline A4 & & & & & & & & .617 \\
\hline A5 & & & & & & & & .520 \\
\hline E1 & & & .720 & & & & & \\
\hline E2 & & & .770 & & & & & \\
\hline E3 & & & .643 & & & & & \\
\hline $\mathrm{T} 1$ & & & & .666 & & & & \\
\hline $\mathrm{T} 2$ & & & & .671 & & & & \\
\hline T3 & & & & .588 & & & & \\
\hline EU1 & & .626 & & & & & & \\
\hline EU2 & & .613 & & & & & & \\
\hline EU3 & & .516 & & & & & & \\
\hline EU4 & & .699 & & & & & & \\
\hline EU5 & & .792 & & & & & & \\
\hline $\mathrm{C} 1$ & & & & & .558 & & & \\
\hline $\mathrm{C} 2$ & & & & & .802 & & & \\
\hline $\mathrm{C} 3$ & & & & & .681 & & & \\
\hline $\mathrm{C} 4$ & & & & & .576 & & & \\
\hline $\mathrm{CS} 1$ & & & & & & & .640 & \\
\hline
\end{tabular}

\begin{tabular}{|c|c|c|c|c|c|c|c|c|}
\hline \multicolumn{9}{|c|}{ Component } \\
\hline & 1 & 2 & 3 & 4 & 5 & 6 & 7 & 8 \\
\hline $\mathrm{CS} 2$ & & & & & & \multicolumn{3}{|c|}{.649} \\
\hline $\mathrm{CS} 3$ & & & & & & \multicolumn{3}{|c|}{.789} \\
\hline
\end{tabular}

Extraction Method: Principal Component Analysis.

Rotation Method: Varimax with Kaiser Normalization.

a. Rotation converged in 11 iterations.

\subsection{Descriptive and Correlation Analysis}

Table 7 displays the means and standard deviations of the eight variables used. The results indicate moderate to high mean values. These statistics described the extent to which the sampled respondents strongly agreed or strongly disagreed with the statements used in the questionnaire based on a five-point rating scale. It is clear that "Ease of use" components have the highest mean equals to 3.5584 and it is followed by "Reliability" components with mean equals to 3.5512. The lowest mean observed in Responsiveness (2.9080).

Table 7. Descriptive Statistics.

\begin{tabular}{llll}
\hline & N & Mean & Std. Deviation \\
\hline Reliability & 250 & 3.5512 & .96826 \\
Responsiveness & 250 & 2.9080 & .92246 \\
Assurance & 250 & 3.4888 & .88046 \\
Empathy & 250 & 3.0990 & 1.32324 \\
Tangible & 250 & 3.5267 & .98876 \\
Ease_Use & 250 & 3.5584 & .90151 \\
Convenience & 250 & 3.3740 & .87675 \\
CuSa & 250 & 3.0600 & .75144 \\
Valid N (listwise) & 250 & & \\
\hline
\end{tabular}

Table 8. Correlations tables for service quality dimensions.

\begin{tabular}{|c|c|c|c|c|c|c|c|c|c|c|}
\hline & & & $\mathbf{R}$ & RS & $\mathbf{A}$ & $\mathbf{E}$ & $\mathbf{T}$ & $\mathbf{E U}$ & $\mathbf{C}$ & $\mathrm{CuSa}$ \\
\hline \multirow[t]{2}{*}{$\mathrm{R}$} & Reliability & $\begin{array}{l}\text { Pearson Correlation } \\
\text { Sig. (2-tailed) }\end{array}$ & 1 & & & & & & & \\
\hline & & $\mathrm{N}$ & 250 & & & & & & & \\
\hline \multirow[t]{3}{*}{ RS } & Responsiveness & Pearson Correlation & $.517 * *$ & 1 & & & & & & \\
\hline & & Sig. (2-tailed) & .000 & & & & & & & \\
\hline & & $\mathrm{N}$ & 250 & 250 & & & & & & \\
\hline \multirow[t]{3}{*}{ A } & Assurance & Pearson Correlation & $.831 * *$ & $.533 * *$ & 1 & & & & & \\
\hline & & Sig. (2-tailed) & .000 & .000 & & & & & & \\
\hline & & $\mathrm{N}$ & 250 & 250 & 250 & & & & & \\
\hline \multirow[t]{3}{*}{$\mathrm{E}$} & Empathy & Pearson Correlation & $.487 * *$ & $.374 * *$ & $.601 * *$ & 1 & & & & \\
\hline & & Sig. (2-tailed) & .000 & .000 & .000 & & & & & \\
\hline & & $\mathrm{N}$ & 250 & 250 & 250 & 250 & & & & \\
\hline \multirow[t]{3}{*}{$\mathrm{T}$} & Tangible & Pearson Correlation & $.780 * *$ & $.476^{* *}$ & $.846 * *$ & $.571 * *$ & 1 & & & \\
\hline & & Sig. (2-tailed) & .000 & .000 & .000 & .000 & & & & \\
\hline & & $\mathrm{N}$ & 250 & 250 & 250 & 250 & 250 & & & \\
\hline \multirow[t]{3}{*}{ EU } & Ease_Use & Pearson Correlation & $.683 * *$ & $.444 * *$ & $.765 * *$ & $.473 * *$ & $.714 * *$ & 1 & & \\
\hline & & Sig. (2-tailed) & .000 & .000 & .000 & .000 & .000 & & & \\
\hline & & $\mathrm{N}$ & 250 & 250 & 250 & 250 & 250 & 250 & & \\
\hline \multirow[t]{6}{*}{$\mathrm{C}$} & Convenience & Pearson Correlation & $.700 * *$ & $.437 * *$ & $.761 * *$ & $.494 * *$ & $.708 * *$ & $.786^{* *}$ & 1 & \\
\hline & & Sig. (2-tailed) & .000 & .000 & .000 & .000 & .000 & .000 & & \\
\hline & & $\mathrm{N}$ & 250 & 250 & 250 & 250 & 250 & 250 & 250 & \\
\hline & $\mathrm{CuSa}$ & Pearson Correlation & $.613 * *$ & $.387 * *$ & $.659 * *$ & $.534 * *$ & $.656 * *$ & $.673 * *$ & $.677 * *$ & 1 \\
\hline & & Sig. (2-tailed) & .000 & .000 & .000 & .000 & .000 & .000 & .000 & \\
\hline & & $\mathrm{N}$ & 250 & 250 & 250 & 250 & 250 & 250 & 250 & 250 \\
\hline
\end{tabular}

**. Correlation is significant at the 0.01 level (2-tailed). 
Pearson correlation was computed to determine the correlation between the variables for this study and the result is displayed in Table 8.

Table 8 showed that there is a positive and significant relationship between all ATM service quality dimensions and customer satisfaction of Rwandan commercial banks, correlation coefficients of customer satisfaction with service quality dimensions are; with reliability $(\mathrm{r}=.613)$, responsiveness $(\mathrm{r}=.387)$, assurance $(\mathrm{r}=.659)$, empathy $(\mathrm{r}=.534)$, tangibles $(\mathrm{r}=.656)$, ease of use $(\mathrm{r}=.673)$ and convenience $(\mathrm{r}=.677)$ and they were all significant at $\mathrm{p}$-values equal to $.000(\mathrm{p}<0.001)$.

The findings furthermore indicate that the first five highest correlation coefficients were calculated between the following dimensions: Assurance and Tangibles $(\mathrm{r}=0.846, \mathrm{p}<0.01)$, Reliability and Assurance $(\mathrm{r}=0.831, \mathrm{p}<0.01)$, Ease of Use and Convenience $(\mathrm{r}=0.786, \mathrm{p}<0.01)$, Reliability and Tangibles $(\mathrm{r}=0.780, \mathrm{p}<0.01)$ and Assurance and Ease of Use $(\mathrm{r}=0.765, \mathrm{p}$ $<0.01)$.

On the other hand, the five lowest correlation coefficients appeared between the dimensions Responsiveness and Empathy $(\mathrm{r}=0.374, \mathrm{p}<0.01)$, Responsiveness and Customer satisfaction $(\mathrm{r}=0.387, \mathrm{p}<0.01)$, Responsiveness and Convenience $(\mathrm{r}=0.437, \mathrm{p}<0.01)$, Responsiveness and Ease of Use $(r=0.444, p<0.01)$ and Empathy and Ease of Use $(\mathrm{r}=0.473, \mathrm{p}<0.01)$.

\subsection{Model Summary}

The value of $\mathrm{R}$ indicates that the model is perfectly fitted and fitness of all research questions of independent variables and dependent variables are quite related with each other. Table 9 of a model summary indicates that the predictor variables of Convenience, Responsiveness, Empathy, Reliability, Ease_Use, Tangible and Assurance have taken. It can be seen that the $\mathrm{R}$ Square value for the model showed that $56.6 \%$ of the variance in the model can be predicted from the seven dimensions of service quality (independents variables).

We find that the adjusted $\mathrm{R}^{2}$ of our model is .553 with $\mathrm{R}^{2}=.566$. This means that the linear regression explains 56.6 per cent of the variance in the data. The Durbin-Watson $d=1.680$, which is between the two critical values of $1.5<\mathrm{d}<2.5$ $(1.5<1.680<2.5)$. Therefore, we can assume that there is no first order linear auto-correlation in our linear regression.
Table 9. Modal Summary ${ }^{b}$.

\begin{tabular}{llllll}
\hline Model & \multirow{2}{*}{$\mathbf{R}$} & $\begin{array}{l}\text { R } \\
\text { Square }\end{array}$ & $\begin{array}{l}\text { Adjusted } \\
\text { R Square }\end{array}$ & $\begin{array}{l}\text { Std. Error of } \\
\text { the Estimate }\end{array}$ & $\begin{array}{l}\text { Durbin- } \\
\text { Watson }\end{array}$ \\
\hline 1 & $.752^{\mathrm{a}}$ & .566 & .553 & .50238 & 1.680 \\
\hline
\end{tabular}

a. Predictors: (Constant), Convenience, Responsiveness, Empathy, Reliability, Ease_Use, Tangible, Assurance.

b. Dependent Variable: CuSa.

Table 10 shows the ANOVA test that presents the overall significance of the regression model in terms of goodness of fit.

Table 10. $A N O V A^{b}$.

\begin{tabular}{lllllll}
\hline Model & $\begin{array}{l}\text { Sum of } \\
\text { Squares }\end{array}$ & df & $\begin{array}{l}\text { Mean } \\
\text { Square }\end{array}$ & F & Sig. \\
\hline \multirow{3}{*}{$1 \quad$ Regression } & 79.523 & 7 & 11.360 & 45.012 & $.000^{\mathrm{b}}$ \\
& Residual & 61.077 & 242 & .252 & & \\
& Total & 140.600 & 249 & & & \\
\hline
\end{tabular}

a. Dependent Variable: CuSa.

b. Predictors: (Constant), Convenience, Responsiveness, Empathy, Reliability, Ease_Use, Tangible, Assurance.

As p-value (.000) is less than 0.05, the model is significant. Thus, Convenience, Responsiveness, Empathy, Reliability, Ease_Use, Tangible and Assurance significantly predict the dependent variable customer satisfaction (F7, 242=45.012; $\mathrm{p}<0.05$ ). This indicates that the model and the data fit well in explaining customer satisfaction.

Therefore, to increase overall satisfaction of ATM service quality, it is rational to concentrate on the improvement of those seven dimensions.

By considering the result of Table 11, it can be seen that for all variables tolerance is greater than 0.1 and VIF is less than 10 (Tolerance $>0.1$ and VIF $<10$ ), this means that there is no multicollinearity in our multiple linear regression model.

Table 11 also displays standardized coefficient Beta and P-values of Reliability $(\beta=0.084, \mathrm{p}>0.05)$, Responsiveness $(\beta=0.000, p>0.05)$, Assurance $(\beta=-0.036, p>0.05)$, Empathy $(\beta=0.182, \quad \mathrm{p}<0.01), \quad$ Tangibles $\quad(\beta=0.170, \quad \mathrm{p}<0.05)$, Ease_of_Use $(\beta=0.245, p<0.01)$, and Convenience $(\beta=0.242$, $\mathrm{p}<0.01)$.

Table 11. Coefficients table.

\begin{tabular}{|c|c|c|c|c|c|c|c|c|}
\hline \multirow{2}{*}{\multicolumn{2}{|c|}{ Model }} & \multicolumn{2}{|c|}{ Unstandardized Coefficients } & \multirow{2}{*}{$\begin{array}{l}\text { Standardized } \\
\text { Coefficients } \\
\text { Beta } \\
\end{array}$} & \multirow[t]{2}{*}{$\mathbf{t}$} & \multirow[t]{2}{*}{ Sig. } & \multicolumn{2}{|c|}{ Collinearity Statistics } \\
\hline & & B & Std. Error & & & & Tolerance & VIF \\
\hline \multirow{8}{*}{1} & (Constant) & .732 & .144 & & 5.075 & .000 & & \\
\hline & Reliability & .065 & .063 & .084 & 1.043 & .298 & .275 & 3.642 \\
\hline & Responsiveness & -.001 & .041 & -.001 & -.015 & .988 & .692 & 1.446 \\
\hline & Assurance & -.031 & .089 & -.036 & -.347 & .729 & .167 & 5.996 \\
\hline & Empathy & .104 & .031 & .182 & 3.378 & .001 & .615 & 1.626 \\
\hline & Tangible & .130 & .064 & .170 & 2.015 & .045 & .251 & 3.988 \\
\hline & Ease_Use & .205 & .063 & .245 & 3.229 & .001 & .311 & 3.218 \\
\hline & Convenience & .207 & .065 & .242 & 3.181 & .002 & .311 & 3.213 \\
\hline
\end{tabular}

a. Dependent Variable: CuSa. 
Table 12. Summary of Hypotheses Analysis.

\begin{tabular}{llllll}
\hline & Hypothesis & Variable & Beta & P-value & Results \\
\hline H1 & Reliability has a significant relationship with customer's satisfaction. & Reliability & .084 & $\mathrm{p}=.298>0.05^{*}$ & Not significant \\
H2 & Responsiveness has a significant relationship with customer's satisfaction. & Responsiveness & .000 & $\mathrm{p}=.988>0.05^{*}$ & Not significant \\
H3 & Assurance has a significant relationship with customer's satisfaction. & Assurance & -.036 & $\mathrm{p}=.729>0.05^{*}$ & Not significant \\
H4 & Empathy has a significant relationship with customer's satisfaction. & Empathy & .182 & $\mathrm{p}=.001<0.05^{*}$ & Significant \\
H5 & Tangibility has a significant relationship with customer's satisfaction. & Tangibles & .170 & $\mathrm{p}=.045<0.05^{*}$ & Significant \\
H6 & Ease of use has a significant relationship with customer's satisfaction. & Ease_Use & .245 & $\mathrm{p}=.001<0.05^{*}$ & Significant \\
H7 & Convenience has a significant relationship with customer's satisfaction. & Convenience & .242 & $\mathrm{p}=.002^{<}<0.05^{*}$ & Significant \\
\hline
\end{tabular}

\section{Discussion}

The study was conducted in five randomly selected commercial banks in the capital city of Rwanda, Kigali (Bank of Kigali, CogeBank, Equity Bank, Banque Populaire du Rwanda SA and Eco Bank) to determine the dimensions of ATM service quality and to explore the relationship between the ATM quality constructs and customer satisfaction. The 29 constructs from seven ATM service quality dimensions (Reliability, Responsiveness, Assurance, Empathy, Tangible, Ease of Use and Convenience) and three constructs of customer satisfaction were used in this study to determine the relationship between ATM service quality and customer satisfaction.

This study was conducted in an urban area and data collected in all three districts of the capital city where the result shows that there a little difference in numbers of respondents from those districts. The $38.8 \%, 33.6 \%$ and $27.6 \%$ of the respondents are from GASABO, KICUKIRO and NYARUGENGE respectively.

Table 4 displayed demographic profile of respondents and it demonstrates that 62 per cent of respondents are in the group of 26-35 years old.

As 70.8 per cent are less of equal aged to 35 years old (range of youths), this means that are using ATMs that other groups of customers.

In terms of gender, 78 per cent are males while females constitute a small number of 22 per cent of all respondents. The results furthermore indicate that 57.6 per cent of respondents are graduates and 17.2 per cent are post-graduate, thus shows that 74.8 per cent of respondents have at least a bachelor's degree.

By considering their occupation, Table 4 shows that employee occupied 54 per cent of the total number of respondents and the second group are Businessmen or business women which has 27.6 per cent. The first two major groups among the customers by considering their monthly income in the present study are 50,001-100,000 and 100,001-200,000 FRW constitute 20.4 and 18.8 per cent to the total. The 69.2 per cent of total respondents have an income of less or equal to $300,000 \mathrm{FRW}$.

The most accessed service of ATM in selected five commercial banks is "Only withdraw money" which constitutes 50.4 per cent of total respondents and the second one is "Withdraw money \& Check account Balance". This means that 90.4 per cent of respondents access only two services of ATM. Furthermore, 32.4 per cent use ATM on alternate days while 27.6 per cent use it once a month. Thus, it is recommended for managers to invest in ATMs that can perform all services and deliver trainings and awareness for those who have such ATMs.

The findings demonstrate that 70 per cent of total number of respondents agreed that they have never been trained in the use of ATM cards and 30 per cent agreed that they have been instructed on how to use of ATM cards. This issue has been declared by [6]: in his research he finds that 32 per cent of respondents only agreed that they have been taught about the utilization of ATM cards.

In Table 3, Cronbach's alpha coefficient was used to analyze internal reliability of variables and all variables were maintained as their coefficient values are greater than 0.7 . Overall, the results from Table 9 of the model summary indicated that all seven independent variables accounted for 56.6 per cent of the variance in customer satisfaction $\left(\mathrm{R}^{2}=.566\right)$.

This means that $56.5 \%$ of the variation in customer satisfaction can be explained by the seven service quality dimensions.

After subjecting the collected data to linear regression analysis, the result of this study indicated that empathy has a positive and significant relationship with customer satisfaction.

This finding was supported by other studies including $[4,8$, $12,16,20]$. However, there is another study reported that empathy has no contribution to customer satisfaction [9].

The findings also indicated that tangibility has a positive and significant relationship with customer satisfaction which was the same result found by $[4,8,9,12,16,20]$.

Furthermore, the result indicated that both ease of use and convenience dimensions have a positive and significant relationship with customer satisfaction and were supported by $[7,20]$.

The result indicated that reliability has a positive and insignificant impact on customer satisfaction and the finding was supported by $[4,9]$. However, it is different from the results of some studies found that reliability has a positive and significant effect on customer satisfaction [7, 8, 12, 19, 20].

The finding again showed that responsiveness has a positive and insignificant impact on customer satisfaction. The finding was the same as the results obtained by $[9,20]$. Differently, there are studies found that responsiveness has a positive and significant effect on customer satisfaction $[4,7,8,12,19]$.

Moreover, the result indicated that assurance has a negative and insignificant effect on customer satisfaction and the result is supported by [16]. On the contrary, assurance has a positive 
and significant effect on customer satisfaction $[4,8,9,12,20]$.

The multiple linear regression analysis reveals that four out of seven independent variables have positive and significant impact on the dependent variable (Customer satisfaction). Thus, the author only accepts four hypotheses (H4, H5, H6 and H7) respectively, i.e. Empathy, Tangibles, Ease_of_Use, and Convenience. On the other hand, the findings showed that Reliability, Responsiveness and Assurance have no significant impact on the level of customer satisfaction.

The results of this study further indicated that ease of use is the most important factor having a positive and significant impact on customer satisfaction followed by convenience, empathy and tangibility by comparing the standardized coefficients (beta $=.245, .242, .182$ and .170 respectively).

\section{Conclusion and Implication of the Study}

\subsection{Conclusion}

The study found that the dominant age group is 26-35 years old that occupied $62 \%$ of total respondents, the group of customers who are below 25 years old showed a portion of $8.8 \%$ and make $70.8 \%$ of respondents to be in the range of youths (age $<=35$ ) in the context of Rwanda.

The most accessed service of ATM is only Withdraw money with $50.4 \%$ followed by Withdraw money and check account balance that appeared to have $40 \%$. This means that $90.4 \%$ of respondents use their ATM cards only for two services. The study has agreed with [6] that customers claimed that they have never been trained in the use of ATM. In this study $70 \%$ of respondents indicated that they did not have an opportunity to be trained in the use of ATMs.

From the seven proposed hypotheses, four hypotheses have been accepted by this study while other three hypotheses have been rejected as they showed greater significance level (Sign. >0.05). Rejected components are Reliability, Responsiveness and Assurance with significance level 0.298, 0.988 and 0.729 respectively. The study concluded that customer satisfied with ATM service quality through empathy, tangibles, ease of use and convenience. It is therefore suggested that bank managers need to improve the performance of those three rejected components in order to satisfied customers and provide a good service quality that may create competitive advantages for the banks in terms of ATM service quality.

\subsection{Limitation}

In this research simple random sample is used to measure seven dimensions of service quality. In future studies, researcher can use another methods and model to evaluate customer satisfaction with ATM SQ. The research was conducted in only five commercial banks of Kigali (Capital city of Rwanda), so it is suggested that future researchers conduct a study in different geographical locations and with other banks. Seven constructs of ATMs service quality
(Reliability, Responsiveness, Assurance, Empathy, Tangibles, Ease of Use and Convenience) have been used to evaluate customer satisfaction with ATMs service quality. It is recommended that future studies use other models like Importance-performance and Expectation-performance models.

\subsection{Implication}

Vis-à-vis academic implications of this research, it is hoped that this investigation had bridged a lacuna and a knowledge gap in the field since such a study was missing in Rwanda and in East Africa. This contribution may act as a springboard for a more comprehensive academic research study in the future, e.g. at a PhD level.

Regarding managerial implications, this study is likely to act as a catalyst for more informed guidelines for policy and practice in the banking sector so that bank managers in Rwanda and East Africa consolidate the strengths of ATMs while eliminating perceived shortcomings as well as offering appropriate training to bank staff. Last but not least, the social implications of this work are that it can raise awareness of ATMs with a larger segment of population. This may lead to a more widespread use of ATMs while building trust in the banking system in Rwanda and East Africa.

\section{References}

[1] H. Iberahim, N. K. Mohd Taufik, A. S. Mohd Adzmir, and H. Saharuddin, "Customer Satisfaction on Reliability and Responsiveness of Self Service Technology for Retail Banking Services,” Procedia Econ. Financ., vol. 37, no. 16, pp. 13-20, 2016.

[2] M. Charles, "Customers satisfaction with ATM banking in Malawi,” African J. Bus. Manag., vol. 8, no. 7, pp. 218-227, 2014.

[3] M. P. Framework, "TOWARDS A P R I C E BASE D MONETARY POLICY FRAMEWORK,” 2018.

[4] S. Akpan, "The Influence of ATM Service Quality on Customer Satisfaction in The Banking Sector of Nigeria," Glob. J. Hum. Resour. Manag., vol. 4, no. 5, pp. 65-79, 2016.

[5] C. Mwatsika, "Impact of ATM Banking Performance on Customer Satisfaction with the Bank in Malawi," Int. J. Bus. Econ. Res., vol. 5, no. 1, p. 1, 2016.

[6] J. B. Harelimana, "The Automated Teller Machines and Profitability of Commercial Banks in Rwanda," vol. 18, no. 1, 2018.

[7] B. Narteh, "Service quality in automated teller machines: An empirical investigation,” Manag. Serv. Qual., vol. 23, no. 1, pp. 62-89, 2013.

[8] R. Prasad, "Service Quality of Automated Teller Machine and Customer Satisfaction: A Case Study of State Bank of India, Patna (Bihar)," Int. J. Manag. Stud., vol. V, no. 4 (5), p. 26, 2018.

[9] C. A. Phan and P. T. Nham, "Impact of service quality on customer satisfaction of automated teller machine service: Case study of a private commercial joint stock bank in vietnam," Bus. Theory Pract., vol. 16, no. 3, pp. 280-289, 2015. 
[10] V. M. Kumbhar, "Customers' Satisfaction in Atm Service: an Empirical Evidences From Public and Private Sector Banks in India,” Manag. Res. Pract., vol. 3, no. 2, pp. 24-35, 2011.

[11] J. J. Cronin and S. a Taylor, "Measuring Quality: A Reexamination and," J. Mark., vol. 56, no. 3, pp. 55-68, 1992.

[12] A. Mohammad and S. Alhamadani, "Service quality perspectives and customer satisfaction in commercial banks working in Jordan," Middle East. Financ. Econ., vol. 14, no. 14, pp. 60-69, 2011.

[13] C. Ugwuegbu, "TANGIBLES AND EMPATHY DIMENSIONS (OF SERVPERF MODEL) AND CUSTOMER SATISFACTION IN THE USE OF ATMs," no. April, 2019.

[14] K. F. Yuen and V. V. Thai, "Service quality and customer satisfaction in liner shipping," Int. J. Qual. Serv. Sci., vol. 7, no. 2-3, pp. 170-183, 2015.

[15] I. Abasimi, A. A. Evans, and A. Y. A. Martin, "Automated Teller Machine (ATM) Service and Customer Satisfaction in the Upper East Region of Ghana," vol. 8, no. 2, pp. 69-75, 2018.

[16] L. Belay and B. Kindie, "The Effect of ATM Service Quality on Customer Satisfaction: Evidences from Customers of Ethiopian Commercial Banks in,” vol. 9, no. 7, pp. 109-116, 2017.

[17] L. Zhou, "A dimension-specific analysis of performance-only measurement of service quality and satisfaction in China's retail banking," J. Serv. Mark., vol. 18, no. 7, pp. 534-546, 2004.

[18] H. C. Hamaker, On multiple regression analysis, vol. 16, no. 1. 1962.

[19] B. Narteh, "Perceived service quality and satisfaction of self-service technology: The case of automated teller machines," Int. J. Qual. Reliab. Manag., vol. 32, no. 4, pp. 361-380, 2015.

[20] B. Narteh, "Service quality and customer satisfaction in Ghanaian retail banks: the moderating role of price," Int. J. Bank Mark., vol. 36, no. 1, pp. 68-88, 2018.

[21] V. Yilmaz, E. Ari, and H. Gürbüz, "Investigating the relationship between service quality dimensions, customer satisfaction and loyalty in Turkish banking sector: An application of structural equation model," Int. J. Bank Mark., vol. 36 , no. 3, pp. 423-440, 2018.

[22] W. M. Lassar, C. Manolis, and R. D. Winsor, Service quality perspectives and satisfaction in private banking, vol. 18, no. 4 . 2000 .

[23] M. Sivakumar, V. Rengarajan, V. V. Anand, S. Srinivasan, M. Kalayanasundaram, and G. R. Saravanakumar, "A study on services quality in ATM services in public sector banks in kanchipuram town," Int. J. Econ. Res., vol. 14, no. 3, pp. 401412, 2017. 